\title{
ROLE OF SYSTEMIC ANTIBIOTICS AND TOPICAL ANTISEPTICS IN RECURRENT ATOPIC DERMATITIS NOT RESPONDING TO TOPICAL IMMUNOSUPPRESSIVES
}

\author{
Parag Sharma
}

${ }_{1}^{1}$ Associate Professor, Department of Dermatology, Terna Medical College, Navi Mumbai.

\section{ABSTRACT}

\section{BACKGROUND}

Atopic dermatitis (AD) is a highly pruritic inflammatory skin disease that results from complex interaction between genetic susceptibility genes and environmental factors resulting in defective skin barrier, defects in innate immune system, heightened immunologic response to allergens and microbial antigens.

The objective of this study is to evaluate the response of systemic antibiotics and topical antiseptics in patients of recurrent atopic dermatitis who were recalcitrant to topical immunosuppressives.

\section{MATERIALS AND METHODS}

100 children attending Dermatology Clinic with recurrent Atopic Dermatitis, not responding to topical immunosuppressives were enrolled in the prospective study. They were treated for 5 days with Systemic Antibiotics, Systemic Antihistamine and Topical Antiseptic. They were followed up on $5^{\text {th }}, 7^{\text {th }}$ and $10^{\text {th }}$ day and evaluated using SCORAD scoring.

\section{RESULTS}

Out of 100 children, lesions of 11 patients resolved after the use of systemic antistaphylococcal antibiotics, topical antiseptics and systemic antihistaminics; 84 patients showed remission after using topical steroids of higher potency combined with systemic antibiotics and topical antiseptics. Only 5 patients on systemic antibiotics and topical antiseptics required systemic steroids. SCORAD score was very useful in evaluating the patient's condition, their response to treatment and decision to start immunosuppressives.

\section{CONCLUSION}

As systemic antibiotics and topical antiseptics were able to reduce erythema and oozing of atopic patches, it shows that microbial colonisation is an important factor in the precipitation of AD. As our study showed optimum results, patients of recurrent AD recalcitrant to topical immunosuppressives should be initially treated with systemic antibiotics, topical antiseptics and systemic antihistaminics. Based on the SCORAD score and efficacy of treatment, the immunosuppressives can be added.

\section{KEYWORDS}

Atopic Dermatitis, Systemic Antibiotics, Systemic Antihistamines, Topical Antiseptics, SCORAD Score.

HOW TO CITE THIS ARTICLE: Sharma P. Role of systemic antibiotics and topical antiseptics in recurrent atopic dermatitis not responding to topical immunosuppressives. J. Evolution Med. Dent. Sci. 2017;6(90):6356-6361, DOI: 10.14260/jemds/2017/1383

\section{BACKGROUND}

Atopic dermatitis (AD) is a highly pruritic inflammatory skin disease that results from complex interaction between genetic susceptibility genes and environmental factors resulting in defective skin barrier, defects in innate immune system, heightened immunologic response to allergens and microbial antigens.(1) Due to disrupted skin barrier, there is increased allergen absorption and microbial colonisation of skin.(2) A defect in the skin's innate immune response leads to less Antimicrobial Peptide generation, thereby causing skin colonisation with Staph. aureus, virus and fungi.

Atopic dermatitis is induced when protein, carbohydrates and glycogen from microbes or allergen on skin surface are presented as antigens by LC (Langerhans cells) to MHC II molecules.(3) In the lymph nodes, the antigens are recognised by CD4 $\mathrm{T}$ cells leading to production of $\mathrm{T}_{\mathrm{H} 2}$ cells. $\mathrm{T}_{\mathrm{H} 2}$ cells releases IL-4, IL-13 and IL-5 cytokines. IL-4 and IL-13

'Financial or Other Competing Interest': None.

Submission 13-10-2017, Peer Review 06-11-2017,

Acceptance 13-11-2017, Published 20-11-2017.

Corresponding Author:

Dr. Parag Sharma,

Flat. No. A-305, Dharti Complex, Plot-60/61,

Sector-18, Kamothe, Navi Mumbai-410209.

E-mail: paragsharma8@rediffmail.com

DOI: $10.14260 /$ jemds $/ 2017 / 1383$ produces IgE, whereas IL-5 activates eosinophils.(4) On activation T cells acquire CLA marker and endothelial cells acquire ICAM-1, VCAM-1 and E-selectin markers.(5) This leads to infiltration of memory $\mathrm{T}_{\mathrm{H} 2}$ cells to skin (primary site of allergen entry).On further entry of allergen or microbes into skin, there is stimulation of FceR1 (IgE receptor) on surface of LC and IEDC (Inflammatory Dendritic Cells) leading to release of proinflammatory signals. This contributes to amplification of allergic immune response producing AD.

Prevalence of $\mathrm{AD}$ is increasing and is about $10 \%-20 \%$ in industrialised countries. AD appears to be more prevalent in highly industrialised societies and advantaged socioeconomic classes.(6) In 90\% cases, onset is before 5 years. AD has 3 stages- Infantile, Childhood and Adulthood each of which may show acute, subacute and/ or chronic skin reaction pattern.

Patients of $\mathrm{AD}$ are predisposed to the development of cutaneous infection, which may exacerbate dermatitis. Bacterial infections contribute to exacerbations of the disease even without grossly visible purulent exudates.(7) Virtually, all patients with severe acute AD will grow $\mathrm{S}$. aureus from swab culture. S. aureus may release exotoxin that function as superantigens and drive the inflammatory cascade that initiates acute AD.(8) Similarly, Herpes simplex or dermatophyte infection may complicate $\mathrm{AD}$ and contribute to exacerbation of disease activity. 


\section{Aims and Objective}

Atopic dermatitis is characterised by periodic recurrences. In many patients, the relapsed patches become refractory to topical immunosuppressives. Such patients are then treated with systemic immunosuppressives. It has been documented that when atopic dermatitis patches are secondarily infected, they become acute and presents as relapses. As antistaphylococcal antibiotics is used for treatment of such infections, this study was conducted to evaluate the response of systemic antibiotics and topical antiseptics in patients of recurrent atopic dermatitis who were recalcitrant to topical immunosuppressives.
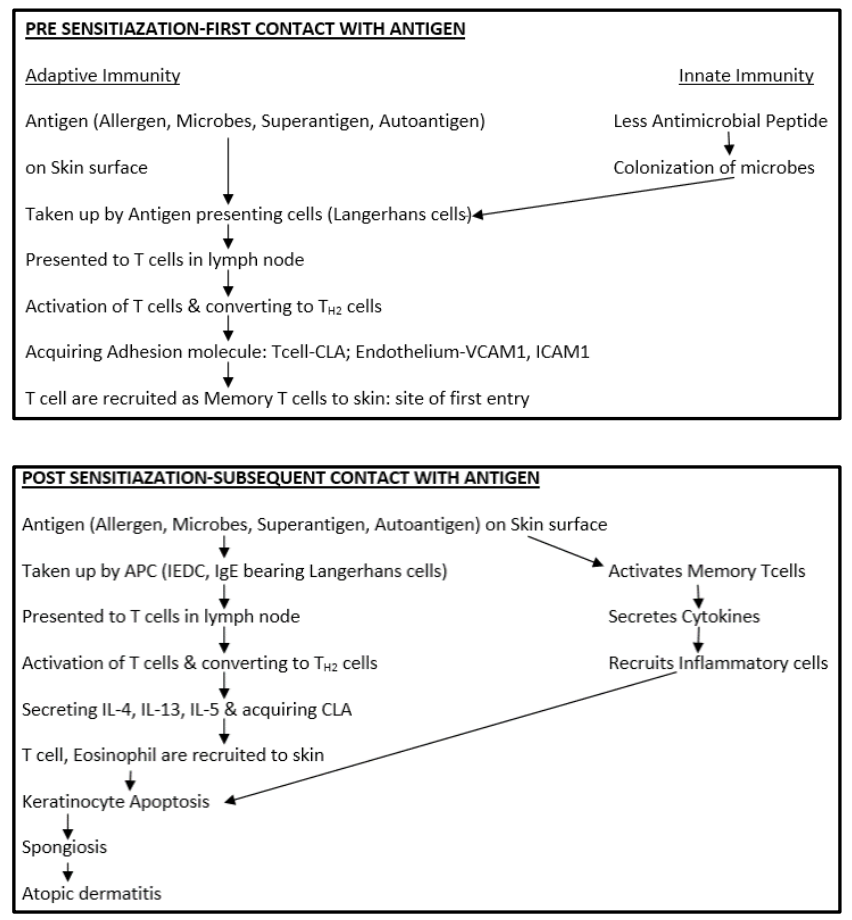

Management of $\mathrm{AD}$ is mainly by preventing dryness of skin, avoiding allergen contact and colonisation of microbes on skin. Once AD develops, Systemic and Topical Immunosuppressives, Systemic Antihistamines and Systemic Antibiotics are used. Systemic and Topical Immunosuppressives has been the cornerstone of treatment of AD. Staph. colonisation is effectively reduced by Antiinflammatory therapies. (9)

Antistaphylococcal antibiotics (Cephalosporins or Penicillinase resistant penicillin) are very helpful in the treatment of patients who are heavily infected with S. aureus.(10) They can be helpful while treating flares of $\mathrm{AD}$ resistant to topical therapy. With the increasing prevalence of community acquired methicillin-resistant $\mathrm{S}$. aureus, there has been renewed interest in using antiseptics to reduce colonisation.

\section{MATERIALS AND METHODS}

Children attending Dermatology Clinic with recurrent Atopic Dermatitis not responding to topical immunosuppressives were enrolled in the prospective study. The study was conducted over 3 years and a total of 100 patients could be included in the study. After diagnosing children included in the study as AD, they were treated and later evaluated using SCORAD scoring.

\section{Inclusion Criteria}

Children between 6 months to 12 years having recurrent AD, not responding to topical immunosuppressives were included in the study. Not responding to topical immunosuppressives means that after using the prescribed topical steroids and/ or calcineurin inhibitors, the $\mathrm{AD}$ patches continued to increase in size and/ or new patches appeared.

\section{Exclusion Criteria}

Children between 6 months to 12 years having recurrent atopic dermatitis with active source of infection were excluded from the study. Active source of infection is indicated by presence of fever, boils, loose motion, burning micturition and productive cough. Irritated kids who are constantly crying and itching were also excluded from the study.

A detailed history, general, cutaneous and systemic examination was done on all patients included in the study. Characteristic features of AD were noted using refined Hanifin and Rajka's criteria.(11) Diagnosis of AD was done as suggested by American Academy of Dermatology Consensus conference on Paediatric Atopic Dermatitis(5) (Table).

\begin{tabular}{|c|c|}
\hline \multicolumn{2}{|r|}{$\begin{array}{c}\text { Essential Features } \\
\text { (Must be Present and are Sufficient for Diagnosis) }\end{array}$} \\
\hline 1 & Pruritus \\
\hline \multirow[t]{4}{*}{2} & $\begin{array}{l}\text { Eczematous changes- Typical morphology and age } \\
\text { specific distribution patterns: }\end{array}$ \\
\hline & $\begin{array}{c}\text {-Facial, neck and extensor involvement in infants and } \\
\text { children }\end{array}$ \\
\hline & -Current or prior flexural lesions in any age group \\
\hline & -Sparing of groin or axillary regions \\
\hline 3 & Chronic or relapsing course \\
\hline \multicolumn{2}{|r|}{$\begin{array}{c}\text { Important features (seen in most cases, support the } \\
\text { diagnosis) }\end{array}$} \\
\hline 1 & Early age of onset \\
\hline 2 & Personal and/ or family history of atopy (IgE reactivity) \\
\hline 3 & Xerosis \\
\hline \multicolumn{2}{|r|}{$\begin{array}{l}\text { Associated features (helpful in suggesting the diagnosis, but } \\
\text { less specific) }\end{array}$} \\
\hline 1 & $\begin{array}{c}\text { Keratosis pilaris/ Ichthyosis vulgaris/ Palmar } \\
\text { hyperlinearity }\end{array}$ \\
\hline 2 & Atypical vascular response \\
\hline 3 & Perifollicular accentuation/ Lichenification/ Prurigo \\
\hline 4 & Ocular/ Periorbital changes \\
\hline 5 & Perioral/ Periauricular lesions \\
\hline
\end{tabular}

Typical morphology includes Acute, Subacute and Chronic skin lesions. All lesions are intensely pruritic and erythematous. Acute skin lesions are seen mainly in infantile stage as vesicle with oozing and crusting on face and extensors. Subacute skin lesions is seen mainly in childhood stage as papule/ plaque with scaling and excoriation of flexures. Chronic skin lesions is seen mainly in adult stage as thickened hyperkeratotic plaque with lichenification and prurigo nodularis on flexural folds.

A diagnosis of $\mathrm{AD}$ was done by excluding conditions like scabies, seborrhoeic dermatitis, contact dermatitis (irritant 
and contact), ichthyosis, cutaneous T-cell lymphoma, psoriasis, photosensitivity dermatosis, immune deficiency diseases and erythroderma of other causes. Patient's extent and severity of eczema was assessed by SCORAD (Scoring Atopic Dermatitis) scale. Patients were further classified as mild, moderate and severe eczema based on the SCORAD scale.(12) SCORAD is calculated by adding area of involvement, intensity of lesions and subjective symptoms.

\section{Area}

The sites affected by eczema are shaded on a drawing of a body. The rule of 9 is used to calculate the affected area (A) as a percentage of the whole body-

- Head and neck- $\quad 9 \%$

- Upper limbs- $\quad 9 \%$ each

- Lower limbs- $18 \%$ each

- Anterior trunk- $18 \%$

- $\quad$ Back- $18 \%$

- Genitals- $\quad 1 \%$

The score for each area is added up to get the total area 'A,' which has a possible maximum of $100 \%$.

\section{Intensity}

A representative area of eczema is selected. In this area, the intensity of each of the following signs is assessed as none (0), mild (1), moderate (2) or severe (3).

- Redness

- Swelling

- Oozing/ crusting

- Scratch marks

- $\quad$ Skin thickening (lichenification)

- Dryness (this is assessed in an area where there is no inflammation)

The intensity scores are added together to give ' $\mathrm{B}$ ' (maximum 18).

\section{Subjective Symptoms}

Subjective symptoms, i.e. itch and sleeplessness are each scored by the patient or relative using a visual analogue scale, where 0 is no itch (or no sleeplessness) and 10 is the worst imaginable itch (or sleeplessness). These scores are added to give ' $\mathrm{C}$ ' (maximum 20).

\section{Total Score}

The SCORAD for that individual is A/5 + 7B/2 + C (maximum 103). Patients were then classified as Mild eczema $(<25)$, Moderate eczema $(>25<50)$ and Severe eczema ( $>50)$.

After patients were diagnosed and evaluated, they were given a 5-day treatment of Systemic Antibiotics (Cefadroxil or Amoxicillin + Clavulanic acid), Systemic Hydroxyzine $(0.5$ $\mathrm{mg} / \mathrm{kg}$ of body weight 3 times daily) and Topical Condy's compress $\left(\mathrm{KMnO}_{4}\right.$ 1:10000). An emollient was advised to be applied only on dry patches 1 hour after Condy's compress application. Topical steroids were stopped. Cefadroxil (20 $\mathrm{mg} / \mathrm{kg}$ of body weight) was prescribed for patients with mild AD. Amoxicillin and clavulanic acid $(30 \mathrm{mg} / \mathrm{kg}$ of body weight) was prescribed for patients with moderate and severe AD.
Patients were asked to follow up on $5^{\text {th }}, 7^{\text {th }}$ and $10^{\text {th }}$ day. They were asked to report immediately if there was aggravation of disease or new patches have appeared. During followup, the patients were evaluated (by SCORAD scale) for pruritus and appearance of new patches.

On $5^{\text {th }}$ day, patients were evaluated for starting topical or systemic immunosuppressives. Patients whose pruritus had reduced were continued on same treatment for further 5 days. Patients whose pruritus has not reduced but patches have improved and no new patches have erupted were given topical steroids in addition to Systemic Antihistamines and Topical Antiseptics. Patients whose pruritus has not reduced, patches have not improved and new patches have appeared were given topical steroids and systemic steroids in addition to Systemic Antihistamines and Topical Antiseptics.

Analyses of the results have been done by using the software SPSS 20.0 version. Chi-square test and Friedman's Chi-square test is used to find out the ' $p$ ' value. $P$ value is used to determine the level of significance.

\section{RESULTS}

\begin{tabular}{|c|c|c|}
\hline \multicolumn{3}{|c|}{ Demographic and Social Factors of Patients } \\
\hline Variables & No. of Patients & Percentage \\
\hline Age Group (yrs.) & & 31 \\
\hline $0-2$ & 31 & 43 \\
\hline $3-4$ & 43 & 21 \\
\hline $5-6$ & 21 & 5 \\
\hline $7-8$ & 5 & 0 \\
\hline $9-10$ & 0 & 0 \\
\hline $11-12$ & 0 & 100 \\
\hline Total & 100 & 44 \\
\hline Sex & & 56 \\
\hline Male & 44 & 100 \\
\hline Female & 56 & 67 \\
\hline Total & 100 & 20 \\
\hline Site & & 37 \\
\hline Face & 67 & 43 \\
\hline Extensors of limbs & 20 & \\
\hline Flexors of limbs & 37 & 49 \\
\hline $\begin{array}{c}\text { Extensors and Flexors } \\
\text { of limbs }\end{array}$ & 43 & 83 \\
\hline $\begin{array}{c}\text { Area of Involvement } \\
\text { (\%) }\end{array}$ & & 100 \\
\hline $10-20$ & 49 & 43 \\
\hline $21-30$ & 8 & \\
\hline $31-40$ & 100 & \\
\hline Total & & \\
\hline
\end{tabular}

\section{Table 1. Demographic and Dermatitis Factors of Patients}

Out of 100 children, there were 56 females and 44 males. 31 kids were in the age group of 0 - 2 years, 43 between $3-4$ years, 21 between 5 - 6 years, 5 between 7 - 8 years and none between 9 - 10 years and $11-12$ years. All patients had pruritus, xerosis and lesions with typical morphology. Family history of atopy was seen in $43 \%$ patients. Face was involved in $67 \%$, while limbs were involved in all patients. Extensors of limbs (20\%), Flexors of limbs (37\%) and both Flexors and Extensors of limbs (43\%) were involved. Pityriasis alba was observed in $28 \%$ patients. Other minor features were present in less than $10 \%$ patients. Cheilitis was seen more during rainy and winter months. Keratoconus and anterior subcapsular cataract was not seen in any patient; 49 patients 
had $10 \%$ - $20 \%$ involvement of the body surface, 43 had $21 \%$ - 30\% involvement and 8 had 31\% - 40\% involvement.

Out of 100 patients taken up/ included in the study, 95 followed up regularly on $5^{\text {th }}, 7^{\text {th }}$ and $10^{\text {th }}$ day; 5 patients showed no improvement and visited the OPD on next day. All 5 of them were started on Systemic Prednisolone $(1 \mathrm{mg} / \mathrm{kg}$ of body weight). All of them improved subsequently. Oral Cyclosporine had to be added to one of them. As the total number of patients was 100 , so the specific number in each group also indicates the percentage.

\begin{tabular}{|c|c|c|}
\hline $\begin{array}{c}\text { Evaluation of Patients } \\
\text { on Fifth Day }\end{array}$ & $\begin{array}{c}\text { No. of } \\
\text { Patients }\end{array}$ & Percentage \\
\hline Pruritus Reduced & 11 & 11 \\
\hline $\begin{array}{c}\text { Pruritus present + No new patches } \\
\text { + Patches improved }\end{array}$ & 72 & 72 \\
\hline $\begin{array}{c}\text { Pruritus present + No new patches } \\
\text { + Patches did not improve }\end{array}$ & 12 & 12 \\
\hline $\begin{array}{c}\text { Pruritus present + New patches + } \\
\text { Patches did not improve }\end{array}$ & 5 & 5 \\
\hline Total & $\mathbf{1 0 0}$ & $\mathbf{1 0 0}$ \\
\hline \multicolumn{2}{|c|}{} \\
Table 2. Evaluation of Patients on Fifth Day \\
\hline
\end{tabular}

\begin{tabular}{|c|c|c|c|}
\hline $\begin{array}{c}\text { Evaluation of } \\
\text { Patients on Fifth } \\
\text { Day }\end{array}$ & $\begin{array}{c}\text { Patients } \\
\text { on Same } \\
\text { Treatment }\end{array}$ & $\begin{array}{c}\text { Patients } \\
\text { with Added } \\
\text { Topical } \\
\text { Steroids }\end{array}$ & $\begin{array}{c}\text { Patients with } \\
\text { Added Topical } \\
\text { and Systemic } \\
\text { Steroids }\end{array}$ \\
\hline Pruritus Reduced & 11 & 0 & 0 \\
\hline $\begin{array}{c}\text { Pruritus present + } \\
\text { No new patches + } \\
\text { Patches improved }\end{array}$ & 0 & 72 & 0 \\
\hline $\begin{array}{c}\text { Pruritus present + } \\
\text { No new patches + } \\
\text { Patches did not } \\
\text { improve }\end{array}$ & 0 & 12 & 0 \\
\hline $\begin{array}{c}\text { Pruritus present + } \\
\text { New patches + } \\
\text { Patches did not } \\
\text { improve }\end{array}$ & 0 & 0 & 5 \\
\hline Total & 11 & 84 & 5 \\
\hline Chi-square test & \multicolumn{3}{|c|}{$200.00^{* *}$} \\
\hline P-value & \multicolumn{3}{|c|}{ Yes } \\
\hline $\begin{array}{c}\text { Significant at 5\% } \\
\text { level }\end{array}$ & \multicolumn{3}{|c|}{} \\
\hline
\end{tabular}

**Statistically, highly significant at $0.01 \%$ level, i.e. $\mathrm{P}<0.001$.

On Fifth Day number of patients continued on same treatment- 11 .
Number of patients to whom topical steroids were added84.

Number of patients to whom topical steroids and systemic steroids were added- 5 .

\begin{tabular}{|c|c|c|c|}
\hline $\begin{array}{l}\text { Evaluation of } \\
\text { Patients on } \\
\text { Seventh Day }\end{array}$ & $\begin{array}{c}\text { Patients } \\
\text { on Same } \\
\text { Treatment }\end{array}$ & \begin{tabular}{|c|} 
Patients \\
with Added \\
Topical \\
Steroids \\
\end{tabular} & $\begin{array}{c}\text { Patients with } \\
\text { Added Topical } \\
\text { and Systemic } \\
\text { Steroids } \\
\end{array}$ \\
\hline Pruritus reduced & 11 & 84 & 5 \\
\hline \begin{tabular}{|c|}
$\begin{array}{c}\text { Pruritus present }+ \text { No } \\
\text { new patches }+ \text { Patches } \\
\text { improved }\end{array}$ \\
\end{tabular} & 0 & 0 & 0 \\
\hline $\begin{array}{c}\text { Pruritus present }+ \\
\text { New patches }+ \\
\text { Patches did not } \\
\text { improve }\end{array}$ & 0 & 0 & 0 \\
\hline Total & 11 & 84 & 5 \\
\hline \multicolumn{4}{|c|}{ Table 3. Evaluation of Patients on Seventh Day } \\
\hline
\end{tabular}

On Seventh Day number of patients continued on same treatment- 11 .

Number of patients to whom topical steroids were added: $(67+17)=84$.

Number of patients to whom topical steroids and systemic steroids were added- 5 .

\begin{tabular}{|c|c|c|c|}
\hline $\begin{array}{c}\text { Evaluation of } \\
\text { Patients on Tenth } \\
\text { Day }\end{array}$ & $\begin{array}{l}\text { Patients on } \\
\text { Same } \\
\text { Treatment }\end{array}$ & \begin{tabular}{|c|} 
Patients \\
with Added \\
Topical \\
Steroids
\end{tabular} & $\begin{array}{c}\text { Patients with } \\
\text { added Topical } \\
\text { and Systemic } \\
\text { Steroids }\end{array}$ \\
\hline Pruritus Reduced & 11 & 84 & 5 \\
\hline $\begin{array}{l}\text { Pruritus present }+ \\
\text { No new patches }+ \\
\text { Patches improved }\end{array}$ & 0 & 0 & 0 \\
\hline $\begin{array}{c}\text { Pruritus present }+ \\
\text { New patches }+ \\
\text { Patches did not } \\
\text { improve } \\
\end{array}$ & 0 & 0 & 0 \\
\hline Total & 11 & 84 & 5 \\
\hline
\end{tabular}

On Tenth Day, number of patients who improved on same treatment- 11.

Number of patients who improved with added topical steroids- 84 .

Number of patients who improved with added topical steroids and systemic steroids- 5 .

\begin{tabular}{|c|c|c|c|c|c|c|}
\hline Factors & \multicolumn{3}{|c|}{ Condition of Patients } & \multirow{2}{*}{$\begin{array}{c}\text { Friedman's } \\
\text { Chi-Square Test }\end{array}$} & \multirow[b]{2}{*}{ P-value } & \multirow[b]{2}{*}{$\begin{array}{c}\text { Significant at 5\% } \\
\text { Level }\end{array}$} \\
\hline Sex & SCORAD $<25$ Mild & $\begin{array}{c}\text { SCORAD } 25 \text { - } 50 \\
\text { Moderate }\end{array}$ & SCORAD > 50 Severe & & & \\
\hline \multicolumn{7}{|l|}{ Male (44) } \\
\hline SC1 & 19 & 22 & 3 & $66.969 * *$ & $<0.001$ & Yes \\
\hline SC2 & 19 & 22 & 3 & & & \\
\hline SC3 & 37 & 7 & 0 & & & \\
\hline SC4 & 44 & 0 & 0 & & & \\
\hline \multicolumn{7}{|l|}{$\begin{array}{l}\text { Female } \\
(56)\end{array}$} \\
\hline SC1 & 22 & 32 & 2 & $93.513^{* *}$ & $<0.001$ & Yes \\
\hline SC2 & 22 & 32 & 2 & & & \\
\hline SC3 & 50 & 6 & 0 & & & \\
\hline SC4 & 56 & 0 & 0 & & & \\
\hline
\end{tabular}




\begin{tabular}{|c|c|c|c|c|c|c|}
\hline $\begin{array}{l}\text { Age Group } \\
\text { (yrs.) }\end{array}$ & & & & & & \\
\hline \multicolumn{7}{|l|}{$0-2(31)$} \\
\hline SC1 & 6 & 25 & 0 & 72.818** & $<0.001$ & Yes \\
\hline SC2 & 6 & 25 & 0 & & & \\
\hline SC3 & 30 & 1 & 0 & & & \\
\hline SC4 & 31 & 0 & 0 & & & \\
\hline \multicolumn{7}{|l|}{$3-4(43)$} \\
\hline SC1 & 27 & 16 & 0 & $43.935^{* *}$ & $<0.001$ & Yes \\
\hline SC2 & 27 & 16 & 0 & & & \\
\hline SC3 & 41 & 2 & 0 & & & \\
\hline SC4 & 43 & 0 & 0 & & & \\
\hline \multicolumn{7}{|l|}{$5-6(21)$} \\
\hline SC1 & 8 & 12 & 1 & $31.674^{* *}$ & $<0.001$ & Yes \\
\hline SC2 & 8 & 12 & 1 & & & \\
\hline SC3 & 15 & 6 & 0 & & & \\
\hline SC4 & 21 & 0 & 0 & & & \\
\hline \multicolumn{7}{|l|}{$7-8(5)$} \\
\hline SC1 & 0 & 1 & 4 & $14.727^{*}$ & 0.002 & Yes \\
\hline SC2 & 0 & 1 & 4 & & & \\
\hline SC3 & 1 & 4 & 0 & & & \\
\hline SC4 & 5 & 0 & 0 & & & \\
\hline \multicolumn{7}{|c|}{ Table 5. Demographic and Treatment Factors based on Different Evaluations of Patients } \\
\hline
\end{tabular}

*Statistically significant at $5 \%$ level, i.e. $\mathrm{P}<0.05$

**Statistically highly significant at $0.01 \%$ level, i.e. $\mathrm{P}<0.001$

\begin{tabular}{|c|c|c|c|c|c|c|c|}
\hline Factors & \multicolumn{3}{|c|}{ Condition of Patients } & \multirow[b]{2}{*}{ Total } & \multirow[b]{2}{*}{$\begin{array}{c}\text { Chi- } \\
\text { Square } \\
\text { Test }\end{array}$} & \multirow[b]{2}{*}{ P-value } & \multirow[b]{2}{*}{$\begin{array}{l}\text { Significant } \\
\text { at 5\% Level }\end{array}$} \\
\hline Sex & $\begin{array}{c}\text { SCORAD }<25 \\
\text { Mild }\end{array}$ & $\begin{array}{c}\text { SCORAD 25-50 } \\
\text { Moderate }\end{array}$ & $\begin{array}{c}\text { SCORAD > } 50 \\
\text { severe }\end{array}$ & & & & \\
\hline \multicolumn{8}{|l|}{ SC1 } \\
\hline Same Treat & 41 & 54 & 5 & 100 & 0.00 & 1.00 & No \\
\hline + Topl. Steroids & 0 & 0 & 0 & 0 & & & \\
\hline + Topl and Sys Str. & 0 & 0 & 0 & 0 & & & \\
\hline Total & 41 & 54 & 5 & 100 & & & \\
\hline \multicolumn{8}{|l|}{ SC2 } \\
\hline Same Treat & 11 & 0 & 0 & 11 & $117.247^{* *}$ & $<0.001$ & Yes \\
\hline + Topl. Steroids & 30 & 54 & 0 & 84 & & & \\
\hline + Topl and Sys Str. & 0 & 0 & 5 & 5 & & & \\
\hline Total & 41 & 54 & 5 & 100 & & & \\
\hline \multicolumn{8}{|l|}{ SC3 } \\
\hline Same Treat & 11 & 0 & 0 & 11 & $36.003^{* *}$ & $<0.001$ & Yes \\
\hline + Topl. Steroids & 76 & 8 & 0 & 84 & & & \\
\hline + Topl and Sys Str. & 0 & 5 & 0 & 5 & & & \\
\hline Total & 87 & 13 & 0 & 100 & & & \\
\hline \multicolumn{8}{|l|}{ SC4 } \\
\hline Same Treat & 11 & 0 & 0 & 11 & 0.00 & 1.00 & No \\
\hline + Topl. Steroids & 84 & 0 & 0 & 84 & & & \\
\hline + Topl and Sys Str. & 5 & 0 & 0 & 5 & & & \\
\hline Total & 100 & $\mathbf{0}$ & $\mathbf{0}$ & 100 & & & \\
\hline
\end{tabular}

** Statistically highly significant at $0.01 \%$ level, i.e. $\mathrm{P}<0.001$

SC 1 - SCORAD on 1 st day of evaluation;

SC 2- SCORAD on $5^{\text {th }}$ day of evaluation;

SC 3-SCORAD on $7^{\text {th }}$ day of evaluation;

SC 4- SCORAD on $10^{\text {th }}$ day of evaluation.

On $1^{\text {st }}$ day 41 patients had mild eczema, 54 patients had moderate eczema, while 41 patients had severe eczema as evaluated by SCORAD scoring.
On $5^{\text {th }}$ day, SCORAD scoring reduced minimally in all patients. On $7^{\text {th }}$ day, SCORAD scoring reduced considerably; 87 patients had mild eczema and 13 patients had moderate eczema, while no patients had severe eczema. 
By $10^{\text {th }}$ day, all 100 patients had mild eczema showing that all of them had improved significantly with treatment. Out of 100 patients, 11 patients were treated only with Systemic Antibiotics, Systemic Antihistamines and Topical Condy's Compress. So 11 patients did not require topical immunosuppressives, 84 patients required topical steroids, while only 5 patients required systemic steroids.

\section{DISCUSSION}

The study group showed that more females were affected by atopic dermatitis and 95\% affected kids were within 6 years of age. This incidence was similar to most of the earlier studies on atopic dermatitis. Major and minor features and sites of involvement were in accordance to previous observations.

Immunosuppressives (topical and systemic) has been the corner stone of treatment of AD.(7) This study is a first of its kind where immunosuppressives (both topical and systemic) were not used initially in treating recurrent $A D$, which was not responding to topical immunosuppressives. In this study systemic antistaphylococcal antibiotics, topical antiseptics and systemic antihistaminics were used.

A significant number of patients(9) resolved only with the use of systemic antistaphylococcal antibiotics, topical antiseptics and systemic antihistaminics; 84 patients showed remission after using topical steroids of higher potency combined with systemic antibiotics and topical antiseptics. Only 5 patients on systemic antibiotics and topical antiseptics required systemic steroids.

This confirms the fact that Staphylococcus colonisation plays a very important role in the recurrence of $\mathrm{AD}$.

A good response in this study indicates that the systemic antistaphylococcal antibiotics and topical antiseptics could eliminate Staphylococcus colonisation in the patient. The addition of topical Condy's compress eliminated the chances of methicillin-resistant S. aureus strain and colonisation by fungus or virus. Stopping previous immunosuppressives for some days and restarting it later with higher potency steroid could have induced a better result. Chronic usage of topical immunosuppressives increases Staphylococcus colonisation. By stopping it the immunosuppressive effect on the skin is reduced, thereby improving the efficacy of the antibiotics and antiseptics. Continuous use of topical immunosuppressives results in tachyphylaxis. On stopping and resuming its use, tachyphylaxis was averted.

Systemic hydroxyzine was also used in optimum dosage, which may have helped in control of pruritus.

Patients with severe AD should be started with Systemic Immunosuppressives and Systemic Antibiotics.

SCORAD score was very important in evaluating the patient's condition and their response to treatment. SCORAD score was very instrumental in taking a decision when to start immunosuppressives.

Previous studies by Hung SH, Lin YT, Chu CY et al showed that patients with severe $\mathrm{AD}$, even without overt infections shows clinical response to combined therapy with antistaphylococcal antibiotics and topical glucocorticoids. In our study, optimum response was seen with combined therapy of systemic antibiotics and topical antiseptics in $\mathrm{AD}$ patient.

\section{CONCLUSION}

AD could be precipitated by colonisation of bacteria on the skin. Relapses could be induced either by bacteria acting as antigen or patches getting secondarily infected. As systemic antibiotics and topical antiseptics were able to reduce erythema and oozing of atopic patches, it shows that microbial colonisation is an important factor in the precipitation of AD. As our study showed optimum results, so patients of recurrent $\mathrm{AD}$ recalcitrant to topical immunosuppressives should be initially treated with systemic antibiotics, topical antiseptics and systemic antihistaminics. Based on the SCORAD score and efficacy of treatment, the immunosuppressives can be added.

\section{REFERENCES}

[1] Leung DYM, Eichenfield LF, Boguniewicz M. Atopic dermatitis. In: Goldsmith LA, Katz SI, Gilchrest BA, et al. eds. Fitzpatrick's Dermatology in general medicine. $8^{\text {th }}$ edn. New York: McGraw-Hill 2012:165-82.

[2] Cork MJ, Danby SG, Vasilopoulos Y, et al. Epidermal barrier dysfunction in atopic dermatitis. J Invest Dermatol 2009;129(8):1892-908.

[3] Taylor RS, Baadsgaard O, Hammerberg C, et al. Hyperstimulatory CD1a+CD1b+CD36+ Langerhans cells are responsible for increased autologous $\mathrm{T}$ lymphocyte reactivity to lesional epidermal cells of patients with atopic dermatitis. J Immunol 1991;147(11):3794-802.

[4] Dworzak MN, Froschl G, Printz D, et al. Skin-associated lymphocytes in the peripheral blood of patients with atopic dermatitis: signs of subset expansion and stimulation. J Allergy Clin Immunol 1999;103(5 Pt 1):901-6.

[5] Kang K, Polster AM, Nedorost ST, et al. Atopic dermatitis. In: Bolognia JL, Jorizzo JL, Rapini RR. eds. Dermatology. 2nd edn. Mosby Elsevier 2008:181-95.

[6] Simpson E, Hanifin JM. Atopic dermatitis. J Am Acad Dermatol 2005;53(1 Suppl 1):115-28.

[7] Williams JV, Vowels B, Honig P, et al. Staphylococcous aureus isolation from the lesions, the hands and anterior nares of patients with Atopic dermatitis. J Emerg Med 1999;17(1):207-11.

[8] Skov L, Baadsgaard O. Bacterial superantigens and inflammatory skin diseases. Clin Exp Dermatol 2000;25(1):57-61.

[9] Hung SH, Lin YT, Chu CY. et al. Staphylococcous colonization in atopic dermatitis treated with fluticasone or tacrolimus with or without antibiotics. Ann Allergy Asthma Immunol 2007;98(1):51-6.

[10] Weinberg E, Fourie B, Allmann B, et al. The use of Cefadroxil in superinfected atopic dermatitis. Curr Ther Res Clin Exp 1992;52(5):671-6.

[11] Hanifin JM, Rajka G. Diagnostic features of atopic eczema. Acta Derm Venereol Suppl (Stockh) 1980;92:44-7.

[12] Severity scoring of atopic dermatitis: the SCORAD Index. Consensus Report of the European Task Force on Atopic Dermatitis. Dermatology 1993;186(1):2331. 